\title{
Aboveground biomass and carbon stock assessment in forest stands of Gmelina arborea Roxb. in Mizoram, North-East India
}

\author{
R.Hauchhum* \\ Department of Forestry, Mizoram University, Tanhril, Mizoram. \\ Date Received: 02-09-2017 Date Accepted: 02-12-2017
}

\begin{abstract}
Aboveground biomass and carbon stock in tropical forest play an important role in global carbon cycle. Assessment of biomass and carbon pool in different forest stands may provide information in making decisions about the carbon management within the forest. Gmelina arborea, a fast growing species that is widely distributed and an important timber species of Mizoram has been chosen to assess its biomass and carbon stock. The present study was carried out to estimate the aboveground biomass and carbon stock in G. arborea in different forest stands of Mamit District, Mizoram, north-east India. The result shows that the total aboveground biomass ranged between 66-108 $\mathrm{Mg} \mathrm{ha}^{-1}$ and carbon stock (30.00$53.20 \mathrm{mg} \mathrm{C} \mathrm{ha}^{-1}$ ). The aboveground biomass and carbon stock was maximum in forest stands (site-III) with highest tree density and diameter class of $30-40 \mathrm{~cm}$ and $40-50 \mathrm{~cm}$ indicating the forest site was mature and undisturbed. The result demonstrates that G. arborea contribute in carbon sequestration and helps in mitigating global warming. Further, the aboveground biomass and carbon sequestration potential was greatly affected by the tree composition, population pressure and anthropogenic activities.
\end{abstract}

Keywords: Aboveground biomass, carbon stock, diameter class, Gmelina arborea, tropical forest

\section{Introduction}

Forests are natural storehouses for biomass and carbon. Forest ecosystem is one of the most important carbon sinks nature has provided; carbon is continuously removed from the atmosphere by forest ecosystem processes and stored both in vegetation and soils (McGuire et al., 2001). Anthropogenic activities, conversion to agriculture and increase industries rapidly decrease the forests worldwide; these are responsible for increases in atmospheric concentration of $\mathrm{CO}_{2}$ and other greenhouse gases, which in turn, are thought to be a primary source for global climate change (Melillo et al., 1996). Thus, forest ecosystem plays a vital role in the global carbon cycle by sequestering a huge amount of $\mathrm{CO}_{2}$ from the atmosphere. Earlier studies indicate that the amount of carbon stored in plant biomass globally exceeds that of atmospheric $\mathrm{CO}_{2}$, and nearly $90 \%$ of the plant biomass carbon is stored in tree biomass (Mooney et al., 2001). The potential of $\mathrm{CO}_{2}$ sequestration intricately linked with site quality, forest type, tree species and age of stand (Huyand Anh, 2008). Biomass and carbon storage in forest ecosystems play significant role in the global carbon cycle (Li et al., 2013: Zhao et al., 2014). Therefore, tree biomass play crucial role for understanding the potential future changes of the climate system. Biomass analysis is an important assessment in the carbon cycle especially, carbon sequestration. Recently, biomass is become an important element in understanding and estimating the carbon pools and fluxes of greenhouse gases from terrestrial biosphere associated with land use and land cover changes (Cairns et al., 2003).

*Correspondence: ramchhanliana85@gmail.com

Tel: +919612322075

ISSN 2235-9370 Print / ISSN 2235-9362 Online (C) University of Sri Jayewardenepura 
The aboveground tree biomass and below ground root biomass both need to be assessed to enable better estimations of total carbon (Hamburg, 2000). Forest biomass accounts for 85-90\% of terrestrial vegetation (Dixonet al., 1994) and the amount of biomass change considerably with land use, disturbance and variation in environmental conditions (Canadell et al., 2007: Luyssaertet al., 2007). Forest ecosystems store carbon in the biomass through photosynthetic process, thereby sequestering carbon dioxide that would or else be present in the atmosphere in large quantity. Undisturbed forest ecosystems are generally highly productive and accumulate more biomass and carbon per unit area compared to other land use systems like agriculture. Thus, forest play key role in global carbon cycle (Canadell et al., 2007; Houghton, 2005) and aboveground biomass and carbon storage have been across different parts of the world (Hoover et al., 2012; Tang et al., 2012).

Many research works had been carried out to study biomass production and carbon stock of tropical forests in different tree species by actual harvest at different ages and allometric equations relating biomass with one or more tree dimensions (Jain and Ansari, 2012). In the scenario of global warming and climate change, it is very essential to assess the biomass production and carbon sequestration using non harvest techniques but through standing trees. Therefore, in this study, a nondestructive approached is adopted to determine the biomass and carbon stock in standing of G. arborea. The present investigation aims to estimate the aboveground biomass and carbon stock of G. arborea in the tropical forest ecosystem of Mamit district, Mizoram to understand the potential of tropical forest to mitigate the climate change at regional level.

\section{Material and methods}

\subsection{Site descriptions}

The study was conducted at four forest stands in Damparengpui, aMamit district situated in the western part of Mizoram. The geographic position of the four study sites is: site-I (2343.'07.19" N and

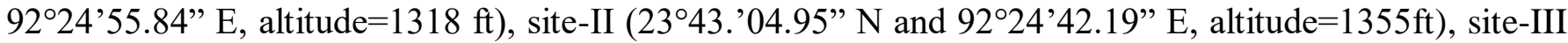

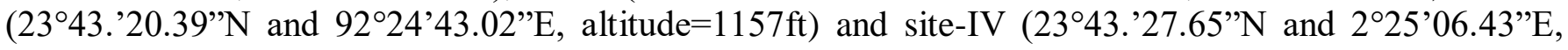
altitude $=1117 \mathrm{ft}$ ). The area of the study sites receives a high rainfall with $2660 \mathrm{~mm}$ annually and the temperature during summer ranged between $25-35^{\circ} \mathrm{C}$ and during winter season $\left(5-15^{\circ} \mathrm{C}\right)$. Soil type of the study area is colluvial, formed along the steeps sided slopes due to accumulation of soil forming materials on slope surface. The study area is a tropical deciduous forest with moderately and steeply slopes which are covered with natural vegetation of tree species like Gmelina arborea, Albizia procera, Steculia villosa, Ficus semicordata, Bischofia javanica and Schima wallichiietc.

\subsection{Field sampling, aboveground biomass, carbon estimation}

Field sampling was carried out at the month of March, 2014 by laying 10 quadrats of $20 \times 20 \mathrm{~m}$ size randomly in each site, the girth of all trees present in the sample plot were measured using measuring tape at breast height $(1.37 \mathrm{~m})$ above the ground, and height of $G$. arborea was measured with the help of an instrument Haga altimeter. The measured girth was converted into diameter using the formula (Diameter=girth/л). Volume was estimated by volumetric equations available in the literature (FSI, 1996). To obtain biomass of each individual species, volume of each tree was multiplied with specific gravity. The carbon stock in each individual tree (G. arborea) was estimated by multiplication of biomass with conversion factor of 0.45 (i.e. $45 \%$ of the biomass). Core segment of the wood (extracted from $G$. arborea) from each site was employed to determine the specific gravity. The wood samples were kept in oven at $100^{\circ} \mathrm{C}$ for 24 hours and specific gravity of $G$. arborea was 0.56 which was used to estimate the aboveground biomass. Calculation of the growing stock for each site was carried out using the formula given below. 


$$
\begin{gathered}
V s p=\Sigma V i \\
V_{p h}=\text {-.-- } V_{s p} \times 10000 \\
a
\end{gathered}
$$

Where:

$$
\begin{array}{ll}
i & =1 \ldots \ldots \ldots \text {. number of tree measured within sample plot } \\
V_{i} & =\text { Volume of single tree } \\
V_{s p} & =\text { Total timber volume within sample plot } \\
V_{p h} & =\text { Timber volume per hectare } \\
a & =\text { Area under the sample plot }
\end{array}
$$

\begin{tabular}{|c|c|c|c|c|c|}
\hline Site & Species & $\begin{array}{c}\text { Mean } \\
\text { DBH }(\mathrm{cm})\end{array}$ & $\begin{array}{c}\text { Mean } \\
\text { Height (m) }\end{array}$ & Density & $\begin{array}{c}\text { Basal cover } \\
\left(\mathrm{m}^{2} / \mathrm{ha}\right)\end{array}$ \\
\hline \multirow[t]{7}{*}{$\mathrm{I}$} & Gmelina arborea & 37 & 16.43 & 220 & 23 \\
\hline & Albizia procera & 35 & & & 6.5 \\
\hline & Stereospermum neuranthum & 34 & & & 3.6 \\
\hline & Sterculia villosa & 18 & & & 0.04 \\
\hline & Schima wallichii & 16 & & & 0.43 \\
\hline & Garuga pinnata & 36 & & & 4.1 \\
\hline & Glochidion arborescens & 24 & & & 0.93 \\
\hline \multirow[t]{7}{*}{ II } & Gmelina arborea & 31 & 12.75 & 210 & 16.1 \\
\hline & Albizia procera & 43 & & & 9.1 \\
\hline & Stereospermum neuranthum & 41 & & & 6.7 \\
\hline & Sterculia villosa & 14 & & & 0.65 \\
\hline & Garuga pinnata & 23 & & & 0.86 \\
\hline & Bischofia javanica & 17 & & & 0.71 \\
\hline & Schima wallichii & 15 & & & 0.39 \\
\hline \multirow[t]{7}{*}{ III } & Gmelina arborea & 34 & 16.45 & 310 & 29.8 \\
\hline & Albizia procera & 35 & & & 7.8 \\
\hline & Sterculia villosa & 15 & & & 3 \\
\hline & Stereospermum neuranthum & 36 & & & 22 \\
\hline & Glochidion arborescens & 20 & & & 2.14 \\
\hline & Bischofia javanica & 22 & & & 0.61 \\
\hline & Schima wallichii & 19 & & & 1.54 \\
\hline \multirow[t]{6}{*}{ IV } & Gmelina arborea & 31 & 17.95 & 230 & 21.3 \\
\hline & Albizia procera & 30 & & & 5.9 \\
\hline & Sterculia villosa & 15 & & & 0.78 \\
\hline & Bischofia javanica & 18 & & & 0.78 \\
\hline & Schima wallichii & 12 & & & 5.71 \\
\hline & Ficus semicordata & 42 & & & 1.38 \\
\hline
\end{tabular}

\section{Results and discussion}

\subsection{Vegetation structure, stand density and basal area}

The highest density of G. arborea was recorded in site-III ( 310 trees ha $\left.{ }^{-1}\right)$ followed by site-IV $\left(230\right.$ trees ha $\left.^{-1}\right)$, site-I $\left(220\right.$ trees ha $\left.^{-1}\right)$ and site-II $\left(210\right.$ trees ha $\left.^{-1}\right)($ Table 1$)$. The mean diameter at breast height (DBH), tree height and basal cover of G. arborea at different sites were listed in Table 1.

Table 1: Tree species composition, density and basal cover at the four forest stands of the study site. 
The number of trees recorded in 20-30 cm and 30-40 cm diameter class was highest compared 40$50 \mathrm{~cm}$,on the other hand, only $4 \mathrm{G}$. arborea species in 50-60 cm diameter class was found in site-I but not in other study sites (Figure 1). The decrease in number of trees in larger diameter class e.g. 40-50 cm and $50-60 \mathrm{~cm}$ of $G$. arborea may be the result of selective felling by the village people for timber and agriculture implements. It indicates large anthropogenic activities and disturbances by the village people in this area that results in forest degradation and deforestation.

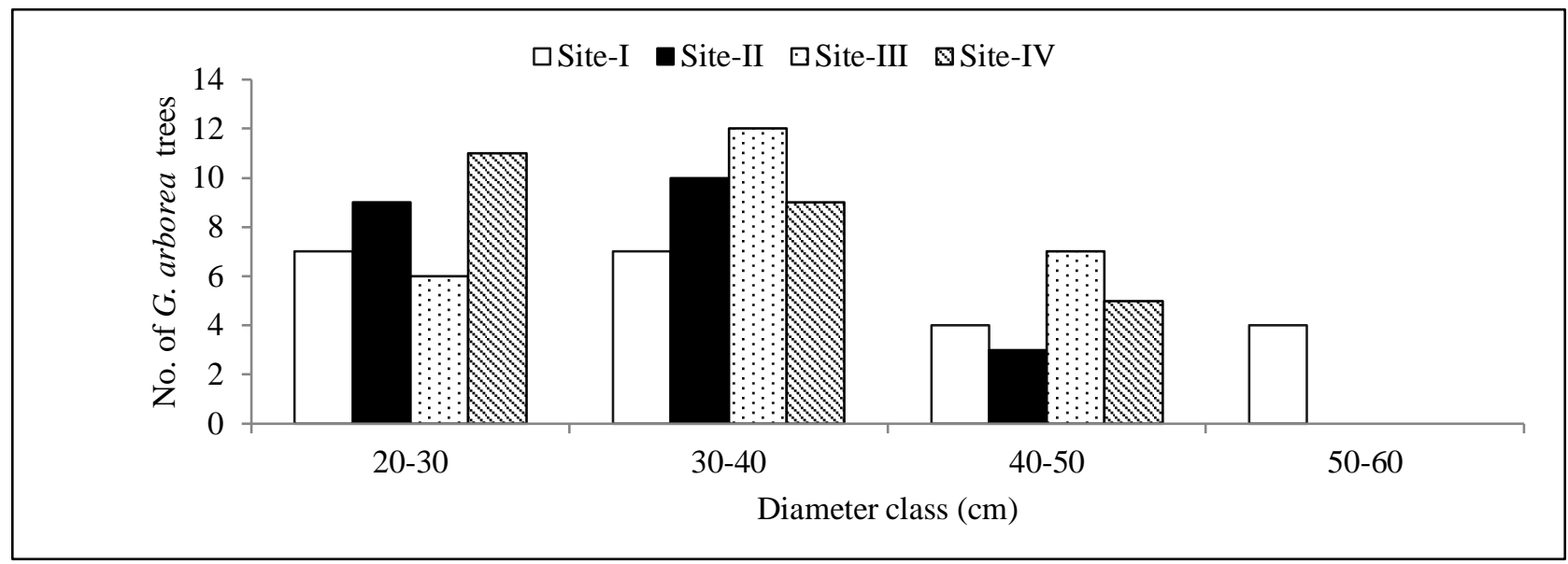

Figure 1: Number of trees (G. arborea) in different diameter class in four forests stands of Mizoram. Relationship of above ground biomass with $\mathrm{DBH}$ and height.

The amount of aboveground biomass and carbon in different diameter class at different sites were depicted in Table 2. The volume of trees increases with increase in diameter class, similarly, the amount of biomass and carbon storage. The amount of aboveground biomass and carbon content in $50-60 \mathrm{~cm}$ diameter was relatively high with $42.32 \mathrm{Mg} \mathrm{ha}^{-1}$ and $19.04 \mathrm{Mg} \mathrm{C}^{-1}$ respectively. The aboveground biomass varied from $10.55-17.51 \mathrm{Mg} \mathrm{ha}^{-1}$ in $20-30 \mathrm{~cm}$ diameter class, $23.16-41.52 \mathrm{Mg} \mathrm{ha}^{-1}$ in $30-40 \mathrm{~cm}$ diameter class and $19.78-43.11 \mathrm{Mg} \mathrm{ha}^{-1}$ in $40-50 \mathrm{~cm}$ diameter class. The variations in aboveground biomass in different diameter class may be the result of changes in number of trees, species composition and basal cover across the study sites. The DBH of G. arborea significantly correlated with volume, aboveground biomass and carbon storage for all the sites at $\mathrm{R}^{2}=0.9686$ for site-I, $\mathrm{R}^{2}=0.9778$ for site-II, $\mathrm{R}^{2}=0.9896$ for site-III and $\mathrm{R}^{2}=0.9583$ for site-IV (Figure 2 ). Similarly, the relationship of tree height with volume, aboveground biomass and carbon storage in $G$. arborea was tested and given in Figure 3 . The relationship of tree height with volume, biomass and carbon in site-I was $\left(\mathrm{R}^{2}=0.4481\right)$, site-II $\left(\mathrm{R}^{2}=0.8580\right)$, site-III $\left(\mathrm{R}^{2}=0.6139\right)$ and site-IV $\left(\mathrm{R}^{2}=0.6851\right)$ indicating that tree height has weak relationship compared to $\mathrm{DBH}$ with tree volume, aboveground biomass and carbon storage.

Table 2: Aboveground biomass $\left(\mathrm{Mg} \mathrm{ha}^{-1}\right)$ and Carbon $\left(\mathrm{Mg} \mathrm{C} \mathrm{ha}^{-1}\right)$ in different diameter class at four forest stands of the study site.

\begin{tabular}{ccccccccc}
\hline Diameter & Site-I & \multicolumn{3}{c}{ Site-II } & \multicolumn{3}{c}{ Site-III } & \multicolumn{3}{c}{ Site-IV } \\
\cline { 2 - 8 } Class $(\mathrm{cm})$ & Biomass & Carbon & Biomass & Carbon & Biomass & Carbon & Biomass & Carbon \\
\hline $20-30$ & 10.55 & 4.75 & 14.46 & 6.51 & 10.85 & 4.88 & 17.51 & 7.88 \\
$30-40$ & 23.16 & 10.42 & 31.39 & 14.12 & 41.52 & 18.68 & 34.42 & 15.48 \\
$40-50$ & 29.91 & 13.45 & 19.78 & 8.91 & 43.11 & 19.39 & 30.59 & 13.76 \\
$50-60$ & 42.32 & 19.04 & & & & & & \\
\hline
\end{tabular}


(a) $\diamond$ Volume $\mathbf{D A B}$ Biomass $\triangle$ Carbon

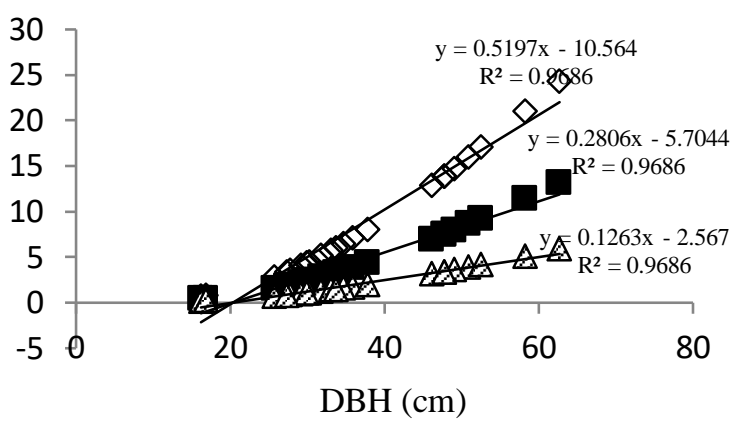

(c) $\diamond$ Volume $\mathbf{D B G}$ Biomass $\triangle$ Carbon

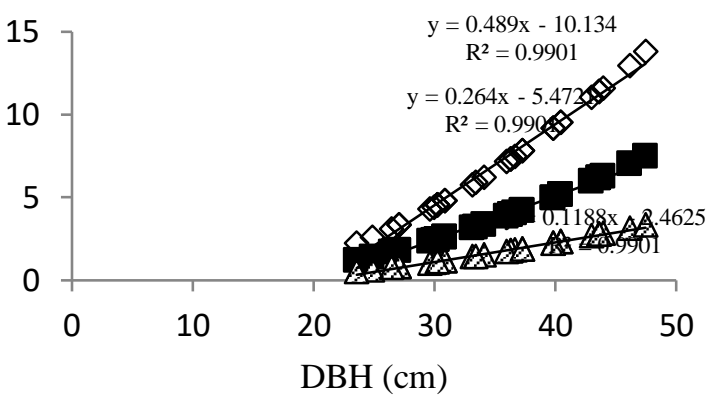

(b) $\diamond$ Volume $\mathbf{A B G}$ Biomass $\triangle$ Carbon

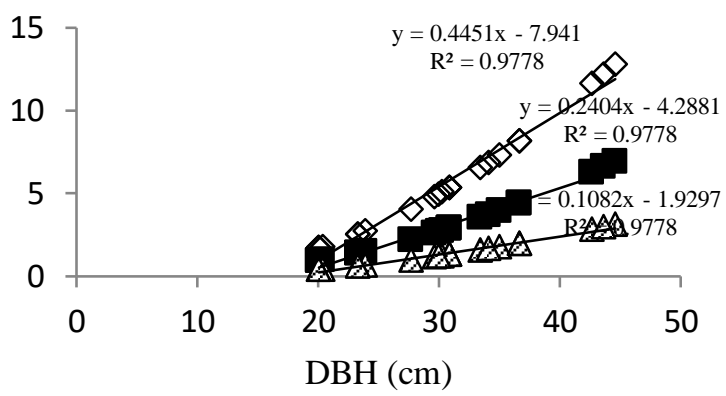

(d) $\diamond$ Volume $\mathbf{A B G}$ Biomass $\triangle$ Carbon

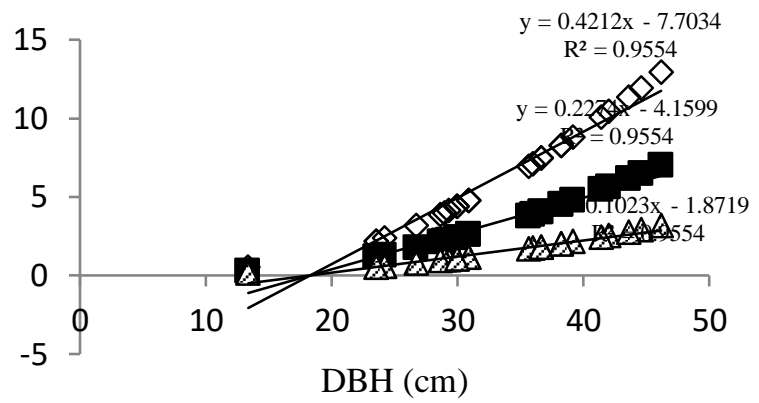

Figure 2:Regression analysis between diameter at breast height (DBH) with volume, aboveground (ABG) biomass and carbon storage in G. arborea in different sites (a) Site-I (b) Site-II (c) Site-III and (d) Site-IV in tropical forest stands of Mizoram.

\subsection{Variation in aboveground biomass and carbon stock in Gmelina arborea}

The amount of total aboveground biomass was highest in site-III with $118.00 \mathrm{Mg} \mathrm{C}^{-1}$ followed site-I (106.00 $\mathrm{Mg} \mathrm{C} \mathrm{ha}^{-1}$ ) and lowest was recorded in $66.00 \mathrm{Mg} \mathrm{C} \mathrm{ha}^{-1}$ ). These results demonstrate that the amount of aboveground biomass varied with site to site depending on the forest type, age of stands and tree density. However, on contrary to the present result, Borah et al. (2013) reported that the aboveground in different species in tropical forest of Cachar district, Assom was not affected by the tree density. The amount of aboveground biomass in the present study are in agreement with earlier studies e.g. Agus et al., (2001), Bohre et al. (2013) and Devagiri. (2013) but relatively lower compared to earlier studies in subtropical forests of Manipur with biomass ranged between 179-246 $\mathrm{Mg} \mathrm{ha}^{-1}$ (Thokchom and Yadava, 2013), sub-tropical broad leave forest (130-255 $\mathrm{Mg} \mathrm{ha}^{-1}$ ) reported by Yadava (2010).

Aboveground carbon estimation described in the literature suggests that carbon constitute between 45 to $50 \%$ of dry matter and it can be estimated by simply taking a fraction of biomass as (Magnussen and Reed, 2004).

$C=0.45 \times B$

Where:

$$
\begin{aligned}
& C=\text { Carbon content } \\
& B=\text { Biomass. }
\end{aligned}
$$


In the present study we followed the above equation to assess the carbon stock in G. arborea at different sites in tropical forest area of Mizoram. The total carbon stock range from $30.00 \mathrm{Mg} \mathrm{Cha}^{-1}$ to 53.20 Mg Cha ${ }^{-1}$ with carbon content was highest in site-III and lowest in site-II. The lowest amount of aboveground biomass and carbon content in Site-II may be the result of low tree density, vegetation composition and anthropogenic disturbance compared to other sites. The age of forest may also influence the potential to sequester carbon (Terakunpisut et al., 2007). On the other hand, increase number of trees, basal area, growing stock and presence of large number of 30-40 cm and 40-50 cm diameter class in site site-III may be responsible for increase aboveground biomass and carbon stock. These indicate that siteIII was mature and less disturbed which favors the growth and development of these forests compared to other sites and have greater rate of carbon sequestration. The present study demonstrates that population pressure and tree density has significant impact on biomass and carbon stock in tropical forest.

(a) Volume $\square$ ABG Biomass $\triangle$ Carbon

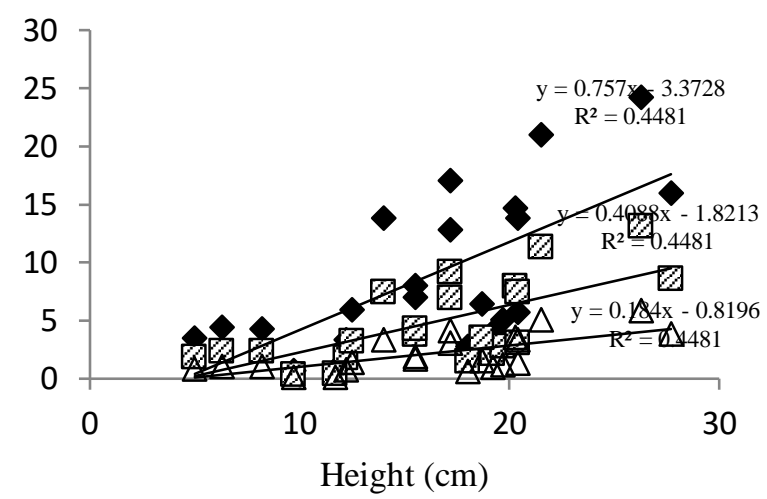

(c) $\bullet$ Volume $\square$ ABG Biomass $\triangle$ Carbon

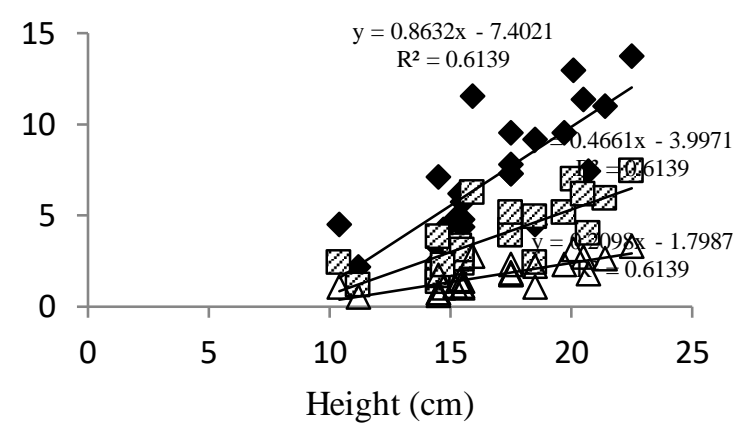

(b) Volume $\otimes$ ABG Biomass $\triangle$ Carbon

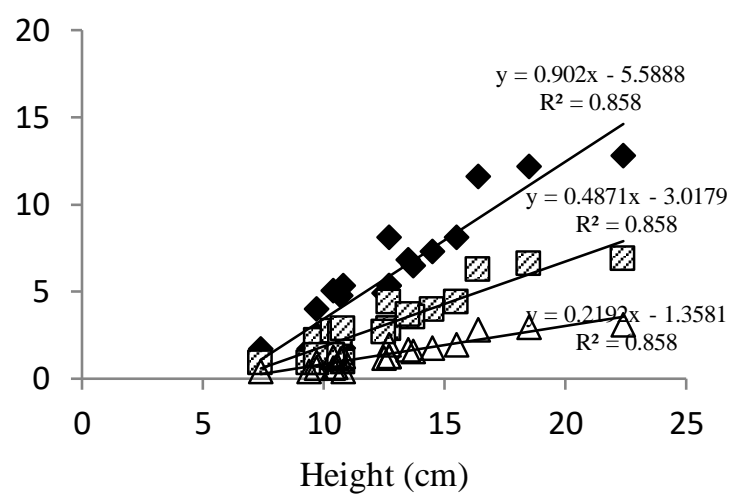

(d) $\bullet$ Volume $\square$ ABG Biomass $\triangle$ Carbon

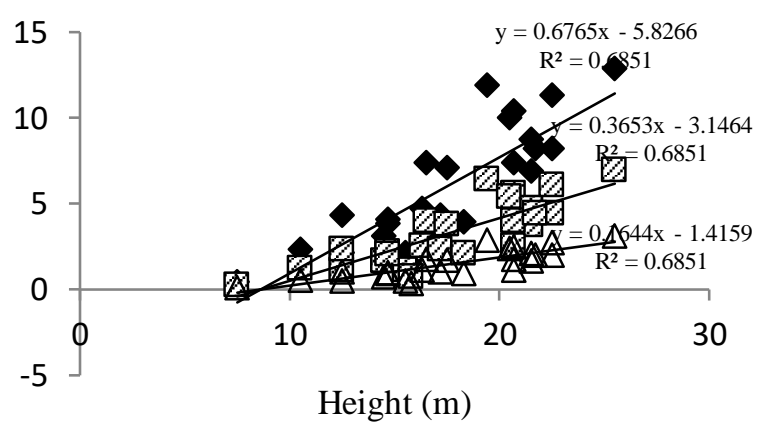

Figure 3: Regression analysis between tree height with volume, aboveground (ABG) biomass and carbon storage in G. arborea in different sites (a) Site-I (b) Site-II (c) Site-III and (d) Site-IV in tropical forest stands of Mizoram.

Table 3: Basal area, total biomass, total carbon and total growing stock at four forest stands of the study site.

\begin{tabular}{ccccc}
\hline Site & $\begin{array}{c}\text { Basal area } \\
\left(\mathrm{m}^{2} \mathrm{ha}^{-1}\right)\end{array}$ & $\begin{array}{c}\text { Total } \\
\text { biomass } \\
\left(\mathrm{Mg} \mathrm{ha}^{-1}\right)\end{array}$ & $\begin{array}{c}\text { Total } \\
\text { carbon } \\
\left(\mathrm{Mg} \mathrm{Cha}^{-1}\right)\end{array}$ & $\begin{array}{c}\text { Total } \\
\text { growing stock } \\
\left(\mathrm{m}^{3}\right)\end{array}$ \\
\hline I & 23.00 & 106.00 & 47.70 & 196.30 \\
II & 16.10 & 66.00 & 30.00 & 121.60 \\
III & 29.80 & 118.00 & 53.20 & 218.80 \\
IV & 21.30 & 82.00 & 36.80 & 151.40 \\
\hline
\end{tabular}




\section{Conclusions}

The present study indicates that aboveground biomass and carbon storage in G. arborea at different sites in tropical forest was highest in forest stands with high tree density, basal area and growing stock. The presence of diameter class with $30-40 \mathrm{~cm}$ and $40-50 \mathrm{~cm}$ has greater potential to carbon sequestration compared to other diameter class. Furthermore, the aboveground biomass and carbon has strong relationship with DBH compared to height of the tree. This indicates that the larger diameter class, the greater carbon sequestration which in turn significantly reduces the carbon level in the atmosphere. The result in the present study shows that G. arborea forest stands in tropical region has a great potential to sequester carbon and the amount of carbon sequestration depends on species composition and anthropogenic activities.

\section{Acknowledgements}

Author is thankful to University Grants Commission (UGC) for financial assistance in the form of Rajiv Gandhi National Fellowship (RGNF) and Department of Forestry, Mizoram University for proving laboratory facility.

\section{References}

Agus, L., Karyanto, O.,hardiwinoto, S.,Na'iem, M.,Kita,S.,haibaraK., Toda, H. 2001. Biomass productivity and carbon stock in short rotation plantation of Gmelina arborea Roxb. in tropical forest. Indonesian Journal of Agricultural Sciences.1, 11-16.

Bohra, N., Nath,A.J.,Das, A.K. 2013. Aboveground biomass and carbon stocks of trees species in tropical forests of Cachar district, Assom, Northeast India. International Journal of Ecology and Environmental Sciences.39, 97-106.

Bohre, P., Chaubey, O.P., Singhal, P.K. 2013.Biomass Accumulation and Carbon Sequestration in TectonagrandisLinn. f. and GmelinaarboreaRoxb. International journal of Bio-Science and BioTechnology.5, 153-173.

Cairns, M.A., Olmsted,L., GradanosJ.,Argaeg,J. 2003. Composition and aboveground tree biomass of dry semi-evergreen forest on Mexico's Yucatan Peninsula. Forest Ecology and Management.186, 125132.

Canadell, J.G., LeQuere, C.,Raupach,M.R.,Field, C.B.,Buitenhuis, E.T.,Ciais,P., J. Conway,T., Gillett,N.P.,Houghton,A.R., Morland,G. 2007. Contribution to accelerating atmospheric $\mathrm{CO}_{2}$ growth from economic activity, carbon intensity and efficiency of natural sink. Proceeding of the National Academy of Science. USA.104, 18866-18870.

Devagiri, G. M., Money, S.,Singh,S.,Dadhawal, V. K.,Patil,P.,Khaple,A. K.,Devakumar, A. S.,Hubballi,S.2013. Assessment of above ground biomass and carbon pool in different vegetation types of south western part of Karnataka, India using spectral modeling. Tropical Ecology.54, 149-165.

Dixon, R. K., Brown, S., Houghton, R.A., Solomon, A.M.,Trexler, M.C., Wisniewki J. 1994. Carbon pools and flux of global forest ecosystem. Science, 263, pp 185-190.

Forest Survey of India, 1996. Volume Equations for Forests of India, Nepal and Bhutan. FSI, Ministry of Environment and Forests, Dehradun.

Hamburg, S.P. 2000. Simple rules for measuring changes in ecosystem carbon in forestry-offset projects. Mitigation and Adaptation Strategies for Global Change.5, 25-37.

Hoover, C.M., Leak, W.B., Keel, B.G. 2012. Benchmark carbon stocks from old growth forests in Northern New England, USA. Forest Ecology Management.266, 108-114.

Huy, B., Anh, T.A. 2008. Estimating $\mathrm{CO}_{2}$ sequestration in natural broad-leaved evergreen forest in Vietnam. Asia-Pacific Agroforestry News (FAO).32, 7-10. 
Jain, A.,Ansari, S.A. 2013.Quantification by allometric equations of carbon sequestered by Tectonagrandis in different agroforestry systems. Journal of forestry research.24, 699-702.

Li, C., Zha, T., Liu, J., Jia, X. 2013. Carbon and nitrogen distribution across a chronosequence of secondary lacebark pine in China. Forest Chronology,89, pp 192-198

Luyssaert, S., Jung,M.,Richardson, A.D., Reichstein, M., Papale, D., Piao, S.L., Schulze, E.D., Wingate, L., Matteucci, G., Aragao,L.,Aubinet,M.,Beer,C.,Bernhofer,C.,Black, K.G.,Bonal,D.,Bonnefond, J.M.,Chambers,J.,Ciais,P.,Cook,B., Davis, K.J., Dolman, A.J.,Gielen,B.,Goulden,M.,Grace,J., Granier,A.,Grille,A.,Griffs,T.,Grunwald,T.,Guidolotti,G., Handson, P.J.,Harding,R., Hollinger, D.Y., Hutgra, L.R.,Kolari,P.,Krujit, B., Kutsch,W.,Lagergen, F., Laurilla, T. 2007. $\mathrm{CO}_{2}$ balance of boreal, temperate, and tropical forests derived from a global database. Global Change Biology.13, 2509-2537.

McGuire, A. D., Sitch,S.,Clein, J.S.,Dargaville,R.,Esser,G.,Foley,J., Wittenberg, U. 2001. Carbon balance of the terrestrial biosphere in the twentieth century: analyses of $\mathrm{CO}_{2}$, climate and land use effects with four process-based ecosystem models. Global Biogeochemical Cycles.15, 183-206.

Melillo, J.M., Hall, D.O.,Agren, G.I. 1996. 'Executive summary', in A. I. Breymeyer, D. O. Hall, J. M. Melillo, and G. I. Agren (eds.), Global Changes: Effects on Coniferous Forests \&Grasslands, John Willey \& Sons Pub., NY.

Mooney, H., Roy, J., Saugier,B. 2001.Terrestrial Global Productivity: Past, Present and Future. Academic Press, San Diego.

Tang, J. W., Yin, J.X., Qi, J.F.,Jepsen, M.R.,Lu, X.T. 2012. Ecosystem carbon storage of tropical forests over limestone in Xishuangbanna, SW China. Journal of Tropical Forest Sciences.24, 399-407.

Terakunpisut, J., Gajaseni, N.,Ruankawe, N. 2007. Carbon sequestration potential in aboveground biomass of Tong PhaPhun national forest, Thailand. Applied ecology and environmental Research.5, 93-102.

Thokchom, A., Yadava,P.S. 2013. Biomass and carbon stock assessment in the sub-tropical forests of Manipur, North-East India. International Journal of Ecology and Environmental Sciences.39, 107113.

Yadava, P.S. 2010. Soil and vegetation carbon pool and sequestration the forest ecosystems of Manipur, Northeast India. In; Qasim, S. Z. \& M. Goel, (Editors) Carbon sequestration Technologies for Clean Energy. Daya Publication House, New Delhi, pp 163-170.

Zhao, J.,Kang,F.,Wang,L., Yu, X., Zhao, W., Song, X., Zhang,Y., Chen, F., Sun,Y., He, T., Han,H. 2014. Patterns of biomass and carbon distribution across a chronosequence of Chinese pine (Pinustabulaeformis) forests. PLoS One.9, e94966. 